\title{
The Study of System Planning of Assets Security on Marine Current Renewable Energy
}

\author{
Arinta Y. Wardani ${ }^{1, *}$, Juniarko Prananda ${ }^{1}$, Irfan S. Arief ${ }^{1}$, and Irwan H. Suherman ${ }^{2}$ \\ ${ }^{1}$ Dept of Marine Engineering, Institut Teknologi Sepuluh Nopember, Surabaya, Indonesia \\ ${ }^{2}$ Center of Research and Develpoment of Marine Geology, Ministry of Energy and Mineral Resources, Bandung, Indonesia
}

\begin{abstract}
Assets have a tendency to be the emergence of potential failures, with the exception of the components in the Marine Current Renewable Energy. The design review of it, related to indications of harm due to environmental conditions. Indications of the failure of the equipment are required to maintain the condition and quality. Problem Identification by Failure Mode Effect Analysis (FMEA) is needed to establish it's components which have a high potential failure. The potential failure of these components will be given as monitoring and specific control systems. Therefore, this research presents node components that need to be secured assets to provide security systems in critical condition with Risk Priority Number (RPN).
\end{abstract}

\section{Introduction}

Indonesia is an archipelago country which has many strait narrows. The condition brings potential effect. It will inflict the water flow speed increases become marine current. In addition, it is potential to generate new energy and renewable. Obviously, the circumstance could be an alternative to solve the electrical problem in this country.

Behind the potential condition, assets are an important thing in Marine Current Renewable Energy. They have a tendency to be the emergence of potential failure. It is necessary to do some preventive measures and analyzes the emergence of modes of potential failure and its consequences. The system planning of asset security design is based on international standard IEC 61400-25 (Wind turbines - Part 25: Communications for monitoring and control of wind power plants). These standards have proven successful applied to the wind power generation system; therefore it is able applied in Marine Current Renewable Energy.

\section{Method}

The research concerns in the scoring of failure criteria asset processed by FMEA (Failure Mode and Effect Analysis). FMEA (Failure Mode and Effect Analysis), a qualitative method to analyze the reliability and mitigate the occurrence of a failure or functional problems of an asset by identifying failure modes that may occur and their causes and consequences [4].

FMEA aims in the following [1]:

- As alternative design to the level of reliability and high safety, especially in the early step of the design of a system.

Ensure all failure modes and effects against an asset has been early predictable and anticipated.

Discover the list of potential failure and magnitude of the effects.

Give the basic qualitative analysis of reliability and availability.

Documenting the failure history of an asset that is useful for reference in the operation and maintenance in the future or even a reference for design changes if necessary.

As the basis for the development of priority corrective measures against assets.

Give justification for the determination of redundancy, failure detection system and automation.

In addition, FMEA is related to Risk Priority Number (RPN). RPN is the priority scale of the risk value for each component of the equipment [3]. RPN value obtained from multiplying the severity $(\mathrm{S})$, occurrence $(\mathrm{O})$ and detection (D). Severity is a value that represents the level of the consequences caused by the failure. The occurrence is a value that represents the frequency of occurrence of the failure mode. Then detection is a value that represents the level of difficulty in detecting the failure mode that appears. The more frequent mode of failure to appear, the 
higher the consequences and the more difficult level detection, the higher also value its RPN [2].

Table 1. Severity Ranking Criteria [4]

\begin{tabular}{|l|l|}
\hline \multicolumn{1}{|c|}{ Rank } & \multicolumn{1}{|c|}{ Description } \\
\hline $1-2$ & $\begin{array}{l}\text { Failure is of such minor nature that the customer (internal or } \\
\text { external) will probably not detect the failure }\end{array}$ \\
\hline $3-5$ & $\begin{array}{l}\text { Failure will result in slight customer annoyance and/or slight } \\
\text { deterioration of part or system performance }\end{array}$ \\
\hline $6-7$ & $\begin{array}{l}\text { Failure will result in customer dissatisfaction and annoyance } \\
\text { and/or deterioration of part or system performance }\end{array}$ \\
\hline $8-9$ & $\begin{array}{l}\text { Failure will result in high degree of customer dissatisfaction } \\
\text { and cause non-functionality of system } \\
\text { cause nonsystem operation or non-compliance with } \\
\text { government regulations }\end{array}$ \\
\hline
\end{tabular}

Table 2. Occurrence Ranking Criteria [4]

\begin{tabular}{|c|c|}
\hline Rank & Description \\
\hline 1 & $\begin{array}{l}\text { An unlikely probability of occurrence during the item } \\
\text { operating time interval. Unlikely is defined as a single } \\
\text { failure mode (FM) probability }<0,001 \text { of the overall } \\
\text { probability of failure during the itam operating time } \\
\text { interval }\end{array}$ \\
\hline $2-3$ & $\begin{array}{l}\text { A remote probability of occurrence during the item } \\
\text { operating time interval (i.e. once every two months). } \\
\text { Remote is defined as a single FM probability }>0,001 \text { but }< \\
0,01 \text { of overall probability of failure during the item } \\
\text { operating time interval }\end{array}$ \\
\hline $4-6$ & $\begin{array}{l}\text { An occasional probability of occurrence during the item } \\
\text { operating time interval (i.e. once a month). Occasional is } \\
\text { defined as a single FM probability }>0,01 \text { but }<0,10 \text { of the } \\
\text { overall probability of failure during the item operating time } \\
\text { interval }\end{array}$ \\
\hline $7-9$ & $\begin{array}{l}\text { A moderate probability of occurrence during the item } \\
\text { operating time interval (i.e. every two weeks). Probable is } \\
\text { defined as a single FM probability }>0,1 \text { but }<0,2 \text { of the } \\
\text { overall probability of failure during the item operating time } \\
\text { interval }\end{array}$ \\
\hline 10 & $\begin{array}{l}\text { A high probability of occurrence during the item operating } \\
\text { time interval (i.e. once a week). High probability is defined } \\
\text { as a single FM probability }>0,20 \text { of the overall probability } \\
\text { of failure during the item operating time interval }\end{array}$ \\
\hline
\end{tabular}

Table 3. Detection Ranking Criteria [4]

\begin{tabular}{|l|l|}
\hline \multicolumn{1}{|c|}{ Rank } & \multicolumn{1}{|c|}{ Description } \\
\hline $1-2$ & $\begin{array}{l}\text { Very high probability that the defect will be detected. } \\
\text { Verification and/or controls will almost certainly detect } \\
\text { the existence of a deficiency or defect }\end{array}$ \\
\hline $3-4$ & $\begin{array}{l}\text { High probability that the defect will be detected. } \\
\text { Verification and/or controls will almost certainly detect } \\
\text { the existence of a deficiency or defect }\end{array}$ \\
\hline $5-7$ & $\begin{array}{l}\text { Moderate that the defect will be detected. Verification } \\
\text { and/or controls will almost certainly detect the existence } \\
\text { of a deficiency or defect }\end{array}$ \\
\hline $8-9$ & $\begin{array}{l}\text { Low that the defect will be detected. Verification and/or } \\
\text { controls will almost certainly detect the existence of a } \\
\text { deficiency or defect }\end{array}$ \\
\hline 10 & $\begin{array}{l}\text { Very low that the defect will be detected. Verification } \\
\text { and/or controls will almost certainly detect the existence } \\
\text { of a deficiency or defect }\end{array}$ \\
\hline
\end{tabular}

To compile an FMEA analysis is required to follow the existing standards, such as by making worksheets that follow the standard MIL-STD-1629A [5]. In case, there will be the number of failure modes that may emerge, thus, need a way to find where the failure mode that will be the priority to be solved. Hence, RPN (Risk Priority Number) is needed to determine the priority.

There are sequences in FMEA:

- Data Collecting, specification, system information and reviewing the system.

- Compile the functional block diagram (FBD) FBD used to describe the different components of the system interact each other. Thus, we can understand the critical path of a system failure.

- Analyze the failure mode and make the worksheets

Determine potential failure modes as examples of the failure mode at the level of manufacturing, which is oversized, cracked, misassembled, and others. Then determine the potential effect of each failure mode. After that determines the potential causes of each failure mode. Then detect the failure through hardware, software, and others.

- $\quad$ Determine the Risk Priority Number (RPN) 
RPN is a critical indicator of the failure mode in the system. It could be calculated by multiplying the severity (1-10), occurrence (1-10) and the detection rank (1-10) with the resulting rated on a scale of 1-1000. The scale has to mean, the smaller value of the RPN, the system is getting better. In the procedure, a system which has a high RPN, corrective actions would be performed on each failure mode.

- Forming the review team.

The technical team has formed the purpose of assessing, comments and feedback on the worksheet that has been compiled and determine priorities based on RPN.

- Obtain the corrective action

- Obtain the monitoring system and control based on RPN.

There are components that must be clustered by FMEA analysis. The components divided into two categories, mechanical and electrical components. The components are included in the mechanical category are main shaft, turbines, bearings, shaft protective pipe, mooring system, and gear box. While the components are included in the electrical category are generators, batteries, inverters, and power control.

\section{Result and Discussion}

The results of this research aim to determine the value of Risk Probability Number (RPN) for each component. The scores of RPN are taken based on the analysis of FMEA tables that have been prepared. From those, can be obtained the average of RPN, which is shown in figure 1.

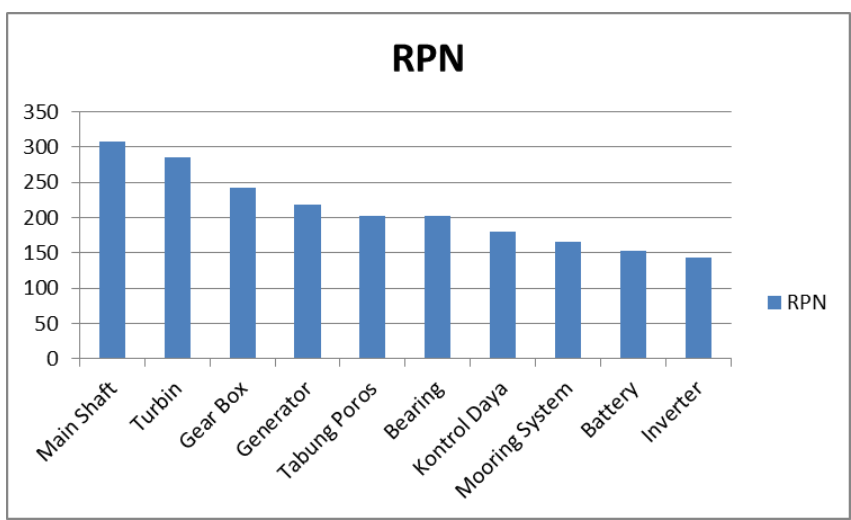

Fig. 1. The RPN of Component of Marine Current Renewable Energy

These are an analysis that shows the score of RPN (Risk Priority Number) of each component. For the main component (main shaft), there are four modes of failure (failure mode) with the potential to occur, which is broken by two different causes permanent changes shape, and not permanently deformed. So that, the failure mode of the four average values obtained RPN to the main shaft is equal to 308. Then, turbine components obtained three potential failure modes, namely blade broken in two different causes and deformed permanently accompanied by corrosion. Thus, from the three failure modes obtained average value RPN to Turbine is at 285 .

Then there is a record for the mooring system, the component is not a critical component, even value its RPN was ranked third from the bottom. But, the value of its severity and occurrence are very lame. This shows that although the mooring system does not include a critical component of the system but the effect is very large if a failure occurs, meaning that the entire system should be switched off when mooring system failed. Therefore, it should be given special treatment (special treatment) of the mooring system by installing sensors that are considered capable of early detection of potential failures occur in the mooring system.

\section{Conclusion}

According to the research done, the following conclusion drawn:

1. The critical values of each component on Marine Current Renewable Energy have been shown in RPN, which scores are taken based on the FMEA analysis.

2. Based on RPN score, main shaft is critical component that needs to be secured in critical condition.

3. In the following research, FMEA analysis is the basis of the planning communications for monitoring and control system on Marine Current Renewable Energy.

\section{References}

1. A.G. Marbun, Failure Mode Implementation and Effect Analysis (FMEA) to Increase Reliability of Boiler Pipe, Jakarta: Teknik Industri, Universitas Mercubuana, (2013)

2. D. Isdarto, Risk Analysis of Operational Failure by Risk Failure Mode and Effect Analysis, Surabaya: Magister Manajemen Teknologi, Institut Teknologi Sepuluh Nopember (2014)

3. K.B. Artana, Risk Assesment Subsea Gas Pipeline, Surabaya: Guna Widya (2013)

4. M. Mraz, FMEA-FMECA (2005)

5. Tuncel and Alpan, Risk Assessment and Management for Supply Chain Networks : Case Study, Izmir: Dokuz Eylul University (2010) 